Journal of Pharmaceutical Science and Medical Reseaarch (PHARMED), 1 (2), 2018, 17-21

Available online at: http://e-journal.unipma.ac.id/index.php/pharmed

ISSN 2614-4840 (print) ISSN 2614-6118 (online)

\title{
Perbandingan Efektivitas Antibakteri Minyak Atsiri Bawang Putih (Allium Sativum) dan Black Garlic terhadap Bakteri Staphylococcus Aureus dan Escherichia Coli dengan Metode Kirby-Bauer
}

\author{
Dwi Pujiastuti ${ }^{1}$, Charlis Palupi ${ }^{2}$ \\ ${ }^{1}$ Prodi Farmasi, Fakultas Ilmu Kesehatan dan Sains, Universitas PGRI Madiun, Madiun, Indonesia \\ ${ }^{2}$ Akademi Analis Farmasi dan Makanan Sunan Giri, Ponorogo, Indonesia \\ E-mail: dhuwie.astuti@yahoo.com
}

Received 07/08, 2018; Accepted 08/10, 2018

\begin{abstract}
Abstrak
Tujuan dari penelitian ini adalah untuk mengetahui daya hambat minyak atsiri pada bawang putih (Allium sativum) dan Black garlic terhadap bakteri Staphylococcus aureus dan Escherichia coli dengan metode Kirby-Bauer. Penelitian ini adalah penelitian eksperimental dengan teknik pengambilan sampel secara sengaja. Hasil dari penelitian ini bahwa kadar minyak atsiri bawang putih (Allium sativum) sebanyak $0,26 \%$, sedangkan pada Black garlic sebanyak $0,15 \%$ dari proses destilasi. Daya hambat terhadap bakteri Staphylococcus aureus dari bawang putih (Allium sativum) yaitu $15,5 \mathrm{~mm}$, sedangkan dari Black garlic yaitu 13,5 mm dan daya hambat terhadap bakteri Escherichia coli dari bawang putih (Allium sativum) yaitu 29,33 $\mathrm{mm}$, sedangkan dari Black garlic yaitu 13,16 mm. Hasil penelitian ini menunjukkan bahwa daya hambat minyak atsiri bawang putih (Allium sativum) dan minyak atsiri Black garlic pada bakteri Staphylococcus aureus tidak ada perbedaan yang bermakna sedangkan pada bakteri Escherichia coli ada perbedaan yang bermakna.
\end{abstract}

Kata kunci: Bawang putih (Allium sativum), Black garlic, Minyak atsiri, Kirby-Bauer.

\section{Comparison Antibacterial Effectiveness of Essential Oil from Garlic (Allium sativum) and Black Garlic Againts Staphylococcus aureus and Escherichia coli with Kirby-Bauer Methods}

\begin{abstract}
This research is to know the inhibitory power of essential oil on garlic (Allium sativum) and Black garlic against Staphylococcus aureus and Escherichia coli bacteria with Kirby-Bauer method. This research is an experimental research with sampling technique is purposive sampling. The result of this research is level of essential oil from garlic (Allium sativum) as much as 0,26\%, whereas in Black garlic is 0,15\% from distillation process. Inhibition power to Staphylococcus aureus bacteria from garlic (Allium sativum) is 15.5 $\mathrm{mm}$, whereas from black garlic is $13.5 \mathrm{~mm}$ and inhibition power to Escherichia coli bacteria from garlic (Allium sativum) is $29,33 \mathrm{~mm}$, while from Black garlic is $13,16 \mathrm{~mm}$. The results of this study indicated that the inhibitory power of garlic essential oil (Allium sativum) and Black garlic essential oil in Staphylococcus aureus bacteria is no significant difference whereas in Escherichia coli bacteria there is a meaningful difference.
\end{abstract}

Keywords: Garlic (Allium sativum), Black garlic, Essential oil, Kirby-Bauer.

\section{PENDAHULUAN}

Penyakit infeksi adalah penyakit yang paling tua dan masih menjadi masalah kesehatan utama, kebanyakan penyakit infeksi di negara berkembang seperti Indonesia adalah penyakit kulit, infeksi saluran pernafasan, infeksi saluran kemih dan diare yang umumnya dapat diobati dengan antibiotik.

Antibiotik bisa diperoleh dari obat tradisional dan tanaman obat sebagai antibakteri. Oleh karena itu, dengan semakin bertambahnya pemahaman ilmu pengetahuan tentang tanaman 
Journal of Pharmaceutical Science and Medical Reseaarch (PHARMED), 1 (2), 2018, 17-21

Available online at: http://e-journal.unipma.ac.id/index.php/pharmed

ISSN 2614-4840 (print) ISSN 2614-6118 (online)

obat, banyak penelitian yang telah meneliti dan merekomendasikan obat tradisional dan tanaman obat menjadi pilihan baru untuk pengobatan infeksi, contohnya adalah bawang putih. Bawang putih (Allium sativum) telah dikenal lama sebagai pemberi aroma dan berpotensi untuk mencegah serta menyembuhkan berbagai penyakit (Amagase et al, 2001), salah satunya adalah penyakit infeksi yang disebabkan oleh bakteri. Bawang putih (Allium sativum) menunjukkan sifat bakteriosid dan bakteriostatis yang luas terhadap bakteri grampositif dan gram-negatif, termasuk terhadap strain yang multi-resisten antibiotik (Fujisawa et al, 2008:11). Di masyarakat bawang putih mentah digunakan untuk kasus pengobatan jerawat, bisul, mengobati sakit gigi, masalah tenggorokan, antibakteri, antidiabetes dan antihipertensi. Semakin berkembangnya teknologi, bawang putih (Allium sativum) banyak diolah menjadi beberapa macam sediaan. Pengolahan bawang putih terbaru dan belum banyak diketahui oleh masyarakat yakni bawang putih yang mengalami proses pemanasan disebut bawang hitam atau Black garlic merupakan produk fermentasi dari bawang putih yang dipanaskan pada suhu $65-80^{\circ} \mathrm{C}$ dengan kelembaban $70-80 \%$ dari suhu kamar selama satu bulan (Wang et al, 2010:37). Black garlic memiliki aroma yang tidak terlalu menyengat, berwarna hitam, dan memilik kadar air yang sedikit sehingga pemanfaatannya bisa langsung dikonsumsi. Masyarakat memanfaatkan Black garlic sebagai obat antihipertensi, antidiabetes, membantu penyembuhan terhadap luka gangren, antikolesterol, menurunkan berat badan dan sebagai antibakteri. Kandungan bawang putih dan Black garlic yang bermanfaat sebagai antibakteri adalah minyak atsiri.

Minyak atsiri dikenal juga dengan nama minyak eteris atau minyak terbang (ethereal oil, volatile oil) yang dihasilkan oleh tumbuhan. Minyak tersebut mudah menguap pada suhu kamar tanpa mengalami dekomposisi, mempunyai rasa getir, berbau wangi sesuai dengan bau tumbuhan penghasilnya, umumnya larut dalam pelarut organik dan tidak larut dalam air (Ketaren, 1985:44). Minyak atsiri didapatkan dengan proses destilasi. Umumnya minyak atsiri digunakan sebagai penurun demam, penghilang masuk angin, antitoksin, pengusir serangga dan juga diketahui sebagai antimikoba. Oleh karena itu, bawang putih dan Black garlic berpotensi sebagai antimikroba karena terdapat kandungan zat minyak atsiri.
Berdasarkan sumber-sumber di atas peneliti melakukan penelitian perbandingan uji efektivitas antibakteri minyak atsiri bawang putih (Allium sativum) dan Black garlic varietas Lumbu Kuning terhadap bakteri Staphylococcus aureus dan Escherichia coli dengan metode Kirby-bauer. Penelitian ini bertujuan untuk mengetahui apakah kandungan minyak atsiri bawang putih (Allium sativum) dan minyak atsiri Black garlic dapat menghambat pertumbuhan bakteri dan apakah ada perbedaan efektivitas antibakteri minyak atsiri pada bawang putih (Allium sativum) dan minyak atsiri pada Black garlic.

\section{METODE}

\section{Alat dan Bahan}

Alat yang digunakan : alat destilasi, alatalat gelas laboratorium merek Iwaki, neraca analitik (Ohaus PA224), cawan petri Anumbra 9 $\mathrm{mm}$, jarum ose, dan inkubator (Memmert IN30).

Bahan yang digunakan : bawang putih segar, black garlic, aquadest steril, media Nutrien Agar (NA), minyak atsiri bawang putih, minyak atsiri black garlic, bakteri Staphylococcus aureus, bakteri Escherichia coli, alkohol 70\%, dan larutan $\mathrm{HNO}_{3}$ (pekat, 69\%).

\section{Prosedur Kerja}

Minyak atsiri didestilasi dengan cara destilasi uap air (water and steam distillation). Destilasi dihentikan sampai minyak tidak keluar dan minyak atsiri yang diperoleh dikumpulkan menjadi satu.

Uji aktivitas antibakteri dimulai dengan menuangkan media ke cawan petri sampai memadat dan menyebarkan biakan bakteri menggunakan kapas steril. Penempatan silinder dilakukan secara terpisah agar zona hambatnya bisa terlihat. Kemudian sampel minyak atsiri diambil menggunakan mikropipet sebanyak $2 \mu 1$ kemudian dimasukkan ke dalam silinder. Media pertumbuhan mikroba diinkubasi selama 24 jam dengan suhu $37^{\circ} \mathrm{C}$ dan diamati zona hambatannya. Blanko nya menggunakan media NA dan aquadest steril. 


\section{HASIL DAN PEMBAHASAN}

Pengambilan minyak atsiri bawang putih (Allium sativum) dan Black garlic dengan metode destilasi. Sampel dikupas dan dipotong kecil-kecil sebelum ditimbang sebanyak 300 gram kemudian dimasukkan ke dalam labu alas bulat $1000 \mathrm{ml}$ dan ditambahkan $600 \mathrm{ml}$ aquadest serta dipanaskan sampai volume yang berkurang sebanyak $450 \mathrm{ml}$. Dari uji tersebut didapatkan kadar untuk bawang putih (Allium sativum) yaitu $0,20 \% ; 0,26 \% ; 0,33 \%$ v/b dan kadar untuk Black garlic yaitu $0,20 \%$; $13 \% ; 0,13 \%$ v/b. Kadar bawang putih lebih banyak dibandingkan kadar Black garlic. Hal ini kemungkinan proses pemanasan yang tidak merata dan bahan yang dipotong tidak seragam karena proses pemotongan menggunakan pisau secara manual sehingga besar tipisnya bahan tidak sama yang akan mempengaruhi keluarnya minyak atsiri.

Pengujian aktivitas antibakteri minyak atsiri bawang putih dan black garlic terhadap bakteri Staphylococcus aureus dan Escherichia coli dilakukan dengan metode Kirby-Bauer, dimana prinsip metode ini adalah pengukuran diameter zona jernih di sekeliling kertas cakram yang berisi zat anti mikroba. Hasil rata-rata nilai zona hambat terhadap bakteri Staphylococcus aureus dan bakteri Escherichia coli dapat dilihat pada tabel berikut:

Tabel 1. Hasil Rata-rata Nilai Zona Hambat terhadap Bakteri Staphylococcus aureus

\begin{tabular}{|c|c|c|c|}
\hline Sampel & $\begin{array}{c}\text { Rata-rata nilai } \\
\text { zona hambat } \\
(\mathbf{m m})\end{array}$ & Sampel & $\begin{array}{c}\text { Rata-rata nilai } \\
\text { zona hambat } \\
(\mathbf{m m})\end{array}$ \\
\hline $\begin{array}{c}\text { Bawang } \\
\text { putih }\end{array}$ & 15,5 & Black garlic & 13,5 \\
\hline
\end{tabular}

Tabel 2. Hasil Rata-rata Nilai Zona Hambat terhadap Bakteri Escherichia coli

\begin{tabular}{|c|c|c|c|}
\hline Sampel & $\begin{array}{c}\text { Rata-rata nilai } \\
\text { zona hambat } \\
(\mathbf{m m})\end{array}$ & Sampel & $\begin{array}{c}\text { Rata-rata nilai } \\
\text { zona hambat } \\
(\mathbf{m m})\end{array}$ \\
\hline $\begin{array}{c}\text { Bawang } \\
\text { putih }\end{array}$ & 29,33 & Black garlic & 13,16 \\
\hline
\end{tabular}

Hasil penelitian dari minyak atsiri sampel bawang putih (Allium sativum) dan Black garlic menunjukkan respon hambatan yang sama yaitu antara 10-20 mm sehingga menurut respon hambatan pertumbuhan Davis dan Stout (1971), minyak atsiri bawang putih (Allium sativum) dan minyak atsiri Black garlic memiliki respon hambatan pertumbuhan yang sama-sama kuat terhadap bakteri Staphylococcus aureus.

Berdasarkan penelitian tersebut kemungkinan zat aktif pada minyak atsiri bawang putih (Allium sativum) dan minyak atsiri Black garlic sama-sama efektif terhadap bakteri Staphylococcus aures karena sifat bakteri yang tidak bergerak dan umumnya tumbuh berkelompok maka akan mudah bagi zat aktif dalam sampel untuk menghambat pertumbuhan bakteri Staphylococcus aures (Radji, 2013:179).

Hasil penelitian dari minyak atsiri sampel bawang putih (Allium sativum) dan Black garlic menunjukkan respon hambatan yang berbeda yaitu sampel bawang putih menunjukkan nilai $29,33 \mathrm{~mm}$ sedangkan Black garlic menunjukkan nilai 13,16 $\mathrm{mm}$, sedangkan menurut respon hambatan pertumbuhan Davis dan Stout (1971) minyak atsiri bawang putih (Allium sativum) memiliki respon hambatan pertumbuhan yang sangat kuat dibandingkan dengan Black garlic yang memiliki respon hambatan hanya kuat terhadap bakteri Escherichia coli. Berdasarkan penelitian tersebut zat aktif pada minyak atsiri bawang putih (Allium sativum) dan minyak atsiri Black garlic memiliki perbedaan yang signifikan dalam menghambat 
Journal of Pharmaceutical Science and Medical Reseaarch (PHARMED), 1 (2), 2018, 17-21

Available online at: http://e-journal.unipma.ac.id/index.php/pharmed

ISSN 2614-4840 (print) ISSN 2614-6118 (online)

bakteri Escherichia coli. Hal ini kemungkinan karena zat aktif pada minyak atsiri bawang putih (Allium sativum) masih kompleks dan belum terurai sehingga lebih efektif menghambat pertumbuhan bakteri Escherichia coli daripada minyak atsiri Black garlic yang kemungkinan zat aktif nya banyak yang terkondensasi melalui reaksi Maillard menjadi senyawa Heyns, tetapi peneliti tidak melakukan penelitian tentang kandungan zat aktif pada minyak atsiri bawang putih (Allium sativum) maupun minyak atsiri Black garlic.

\section{KESIMPULAN}

Kandungan minyak atsiri pada bawang putih (Allium sativum) dan Black garlic mampu menghambat pertumbuhan bakteri Staphylococcus aureus dan Escherichia coli dilihat dari hasil ratarata uji daya hambat dan respon hambatan pertumbuhan bakteri. Besarnya daya hambat yang diperoleh terhadap bakteri Staphylococcus aureus dari sampel minyak atsiri bawang putih (Allium sativum) yaitu $15,5 \mathrm{~mm}$ (kuat), sedangkan dari sampel minyak atsiri Black garlic yaitu 13,5 mm (kuat) dan besarnya daya hambat yang diperoleh terhadap bakteri Escherichia coli dari sampel minyak atsiri bawang putih (Allium sativum) yaitu 29,33 mm (sangat kuat), sedangkan dari sampel minyak atsiri Black garlic yaitu 13,16 mm (kuat).

\section{UCAPAN TERIMA KASIH}

Penulis ingin menyampaikan ucapan terimakasih kepada pihak-pihak yang sangat mendukung penulis dalam pembuatan dan penyusuan karya tulis ilmiah ini, adapun yang dimaksud adalah kepada Allah SWT, kedua orang tua, dan kepada pihak-pihak yang telah membantu terselesainya penelitian ini.

\section{DAFTAR PUSTAKA}

Agusta, andria. 2000. Minyak Atsiri Tumbuhan Tropikal Indonesia. Bandung: ITB Press.

Dawis, W and Stout. 1971. "Disk plate methods of microbiological antibiotic assay". Microbiology, (Online), Vol 22(4):659-665, (http://www.ncbi.nlm.gov), diakses 25 Maret 2017.

Depkes. 1995. Materia Medika jilid 6. Jakarta: Depkes.
Entjang, Indah. 2003. Mikrobiologi dan Parasitologi. Jakarta: EGC.

Guenther, E. 1990. Minyak Atsiri jilid IVA. Jakarta: UI Press.

Gunawan, Didik dan Sri Mulyani. 2004. Ilmu Obat Alam (farmakognosi) jilid 1. Depok: Swadaya.

Harborne, J.B. 1987. Metode Fitokimia (Penuntun Cara Modern Menganalisa Tumbuhan). Bandung: ITB Press.

Harmita dan Maksum Radji. 2005. Buku Ajar Analisis Hayati. Jakarta: Ari Cipta.

Irianto, Koes. 2006. Mikrobiologi (Menguak Dunia Mikroorganisme) jilid 2. Bandung: Yrama Widya.

Jaksa, Suherman. 2010. "Minyak Atsiri dari Berbagai Tanaman Obat". Journal Kedokteran dan Kesehatan, (Online), Vol 6(1):3-4, (http://portalgaruda.org), diakses 18 Maret 2017.

Jawet, Melnick and Adelberg. 1984. Mikrobiologi Kedokteran edisi 16. Jakarta: EGC.

Jawet, Melnick and Adelberg. 2004. Mikrobiologi Kedokteran edisi 23. Jakarta: EGC.

Ketaren, S. 1985. Pengantar Teknologi Minyak Atsiri. Jakarta: Balai Pustaka.

Kuswardhani, Dian S. 2016. Sehat Tanpa Obat dengan Bawang Merah-Bawang Putih. Yogyakarta: Rapha Publishing.

Lay, Bibiana.1994. Analisis Mikroba di Laboratorium. Jakarta: Raja Grafindo.

Pijoto, Setijo dan Zumiati. 2006. Kumpulan Seri Pertanian. Semarang: Aneka Ilmu.

Pratiwi, S.T. 2008. Mikrobiologi Farmasi. Jakarta: Erlangga.

Radji, Maksum. 2013. Buku Ajar Mikrobiologi. Jakarta: EGC. 
Journal of Pharmaceutical Science and Medical Reseaarch (PHARMED), 1 (2), 2018, 17-21 Available online at: http://e-journal.unipma.ac.id/index.php/pharmed

ISSN 2614-4840 (print) ISSN 2614-6118 (online)

Rohmad, A. 2007. Kimia Farmasi Analisis.

Yogyakarta: Pustaka Pelajar.

Sasaki J, Kita J. 2003. "Bacteriocidal Activity of Black garlic Powder Against Bacillus anthracis". Journal of Nutrition Science Vitaminology. (Online). (49) : 519-552, diakses 18 Januari 2017

Setywati, Priantika. 2014. "Aktivitas Antibakteri Ekstrak Umbi Bawang Putih (allium sativum) dengan Lama Fermentasi yang Berbeda Terhadap Pertumbuhan Staphylococcus aureus". Skripsi Tidak Diterbitkan. Surakarta: Universitas Muhammadiyah Surakarta. 
